\title{
Effect of different rootstocks on plant growth, yield and quality of watermelon
}

\author{
S.F. El-SayedA, H.A. HaassanA'C and M.A.GaaraB \\ Vegertable Crops Department, Faculty of Agriculture, Cairo University, Giza, Egypt. \\ Experimental Farm Station of Sakata Seed Company, Ismalia, Egypt. \\ cAuthor for correspondence: e-mail: Sayedfathey2000@yahoo.com
}

\begin{abstract}
This study was conducted in the experimental farm of Sakata Seed Company, located in Ismalia Governorate, Egypt in 2012 and 2013. Watermelon [Citrullus lanatus (Thunb.) Matsum and Nakai] cultivar Aswan F1 was grafted onto 5 different rootstocks, namely, 6001, Squash 3, Kazako, Emphasis and Argentario. The ungrafted Aswan watermelon cultivar was used as the control. Plants were grown in sandy soil under open field conditions. The results showed that while survival rate was low (64\%) in control, it ranged from $82.0 \%$ to $100 \%$ in grafted plants. Grafted plants showed more vigorous vegetative growth than the control plants. When the soil was heavily infected with soil borne diseases, in the first season, the control plants had 7.987 ton/fed yield, while all types of rootstocks produced 30-127 \% higher yield than the control. When the soil was free from soil borne diseases, in the second season, the control plants had 16.178 ton/fed yield, while grafted plants produced 9-13\% higher yield than the control. In contrast, Kazako rootstock had $12 \%$ less yield than the control. This could be attributed to incomplete compatibility of Kazako rootstock. Length and diameter of fruit and rend of fruit were positively influenced by grafting in the first year, while TSS\% was significantly reduced by grafting in the second season. The study showed the importance of using grafting in heavily infected with soil borne diseases and importance of choosing the rootstocks that positively influence plant growth as well as yield and quality of scion fruit for the commercial use of grafting in watermelon fields.
\end{abstract}

Keywords: grafting, survival rate, plant growth, yield, watermelon.

\section{Introduction}

The production of grafted plants first began in Japan and Korea in the late 1920s with watermelon (Citrullus lanatus (Thunb.) Matsum. \& Nakai var. lanatus) grafted onto gourd rootstock (Davis et al., 2008). In the beginning, grafting was adopted to reduce the effect of soilborne disease like Fusarium wilt (Scheffer 1957 ; Lee 1994 ; Ioannou 2001 ; Davis et al., 2008 ) . However, at present, grafting is being used for improving yield (Bersi 2002 ; KacjanMarsic and Osvald 2004 ; Davis et al., 2008), enhancing nutrient uptake (Ruiz et al., 1997; Colla et al., 2010b ), increasing the synthesis of endogenous hormones (Proebsting et al. 1992 ; Dong et al., 2008 ), improving water use efficiency (Cohen and Naor 2002 ; Rouphael et al., 2008a ), reducing uptake of pollutants from agricultural soils (Otani and Seike 2006, 2007) and limiting the toxic effect caused by boron, copper, cadmium and manganese in many crops (Edelstein et al., 2005; Arao et al., 2008; Rouphael et al., 2008b; Savvas et al., 2009). In many cases, grafting was also used to alter hormonal production which in turn influences sex expression and flowering order of grafted plants (Satoh 1996).

The use of grafted seedlings in Cucurbits has been greatly increased in recent years in many of the major vegetable producing regions of the world. More than 700 million grafted seedlings were estimated to have been produced in 2008 in Korea and Japan alone (Lee et al., 2010). The use of grafted seedlings is expected to increase rapidly throughout the world during the next few decades (Davis et al., 2008; Lee et al., 2010). Cucurbit plants are grafted onto various rootstock species and varieties using a range of grafting methods. Cucurbit crops that are commonly grafted include watermelon, melon and cucumber. The most common rootstocks for watermelon are bottle gourd, interspecific hybrids between Cucurbita maxima and Cucurbita moschata and wild watermelon (C. lanatus var. citroides) (Davis et al., 2008). The compatibility of watermelon with any of these rootstocks is generally high, although there is variability within the species (Yamamuro and Marukawa, 1974). The most commonly used Cucurbita spp. rootstock is an interspecific C. maxima $\times$ C. moschata hybrid (Colla et al., 2010a).

In cucurbits such as watermelon, grafting over bottle gourd [ Lagenaria siceraria (Mol.) Standl.] results in early formation of female flowers (Satoh, 1996 ). However, in some cases like pumpkin ( Cucurbita maxima Duchesne), bottle gourd, wax gourd [ Benincasa hispida (Thunb.) Cogn.] and watermelon-grafted watermelon, especially in plants with 'Shintoza'-type rootstocks ( C. maxima Duchesne $\times$ C. moschata Duchesne), flowering was delayed (Yamasaki

et al. 1994 ).

Changes in grafted cucurbit fruit quality appear to be both rootstock, and scion-dependent, causing contradictory reports in the literature. some workers 
have used grafting to improve quality of cucurbit fruits (Colla et al., 2006), such as TSS content (Salam et al., 2002), flesh firmness (Davis and Perkins-Veazie, 2005), lycopene (Davis and PerkinsVeazie, 2005; Proietti et al., 2008), total carotenoids (Liu et al., 2003) by 40\% (Proietti et al., 2008) and amino acids, by up to $35 \%$ (Lee et al., 1996), though there are contradicting views on this particular beneficial effect of grafting in vegetable crops. In this respect, it was reported that grafting cause reduction in watermelon quality concerning textural quality and firmness (Yamasaki et al., 1994), sugar content of both watermelon and melon (Yao et al., 2003; Lopez-Galarza, et al., 2004; Xu et al., 2005c; Liu et al., 2006; Alexopoulos, et al., 2007). In contrast, other scientists found no difference in soluble solids between grafted and non-grafted (Miguel et al., 2004; Colla et al., 2006). The most common complaints about grafted watermelon quality are lowBrix, insipid taste, increased number of yellowish bands in the red flesh, and internal flesh breakdown (Lee and Oda, 2003; Davis et al., 2008a). The deterioration of watermelon fruit quality on Cucurbita spp. rootstocks was attributed to vigorous nutritional uptake (Shinbori. et al., 1981). Taken together, reports to date indicate that depending on the rootstock-scion selection, fruit yield and quality attributes may be either positively or negatively affected by grafting (Oda, 1999; Pulgar et al., 2000; Huh et al., 2003; Yetisir and Sari, 2003; Gao and Liao 2006; Xu et al., 2006

In Egypt, Mounir (1965) produced grafted watermelon plants on many rootstocks for protection from fusarium wilt. Kapiel et al. (2005) observed that the fruit size of watermelons grafted to rootstocks having vigorous root systems is often significantly increased compared to fruits from intact plants. ElEslamboly (2010) found also that, grafting watermelon positively affected on plant vigor and plant height. Grafting Aswan hybrid on different rootstocks gave significant increases in fruit rind thickness and firmness compared with ungrafted plants. Abd El-Wanis et al. (2013) found that grafting of watermelon (Aswan F1 hybrid) on bottle gourd rootstock (Lagenaria siceraria) local variety showed significant increment in most studied characteristics such as vegetative growth (plant height, stem diameter, leaf area, number of leaves, number of branches, plant fresh and dry weight and dry matter percentage), early and total yield in addition to fruit characters, as compared with nongrafted watermelon (control).

The objective of the present work was study the effect of grafting using different rootstocks on the yield and quality of watermelon.

\section{Material and Methods}

Two experiments were conducted during the summer seasons of 2012 and 2013 to study the effect of grafting using different rootstocks on the yield and quality of watermelon (Citrullus lanatus (Thunb.) Matsum \& Nakai var. lanatus) cultivar "Aswan F1" under open field conditions. The experiment was conducted in sandy soil in the experimental farm of Sakata Seed Company, located in Ismalia Governorate, Egypt.

Treatments:

Six treatments were used, i.e. five grafting rootstocks and control treatment (without grafting),

Rootstocks:

The rootstocks used in the first season were as follows:

1. Argentario (Lagenaria siceraria (Mol.) Standl, Syngenta, Milano, Italy.

2. Emphasis - (Lagenaria siceraria) (Molina) Standl) Syngenta, Milano, Italy.

3. Kazako (Cucurbita ficifolia X Cucurbita maxima) Syngenta, Milano, Italy.

4. Squash 3 (Cucurbita pepo, Sakata Seeds, Japan).

5. 6001 (Cucurbita maxima $\times$ C. moschata), Nunhems Zaden (The Netherlands),

6. Non-grafting

Grafting method

Cut (hole insertion) grafting method was used according, to the methods described by Kawaide (1985)

1. Rootstock seeds were sown in seedling foam trays (84 eyes) filled with a mixture of Peat Moss: Vermiculite $(1: 1 \mathrm{v} / \mathrm{v})$ under plastic house on 28 th February 2012 (for the first season and on 24 th February 2013 (for the second season), while watermelon scion seeds were also sown in seedling foam trays ( 84 eyes) filled with the same medium of rootstocks but on 11 th and 7 th March and in the first and second season, respectively.

2. After germination and appearance of the first true leaf of rootstock seedlings, they were located in $10 \mathrm{~cm}$. back plastic bags, containing the same mixture of Peat moss and vermiculite $(1: 1 \mathrm{v} / \mathrm{v})$, supplemented with $50 \mathrm{~g}$. of a fungicide for each 50 $\mathrm{kg}$ of the mixture.

3. Seedling of rootstocks and the scions were ready for grafting at the appearance of the second true leaf on 27th and 23th March in 2012 and 2013, respectively.

4. Seedlings of rootstocks were picked between the two cotyledons after removing the top of the seedling with a razor blade, creating a $\mathrm{V}$-shaped cut between the cotyledons. An inverse V-shaped cut was made on the stem of the scion, $2 \mathrm{~cm}$ below the cotyledons, to fit the cut in the rootstock. Scion and rootstocks were held with a grafting clip.

5. The seedlings were placed under plastic tunnel for optimum temperature and humidity.

6. The compatibility was determined after 7 days in relatively high temperature $25-30 \mathrm{oC}$, from conducting after grafting stage watching the new growth on the scions. 
7. The plastic tunnel was gradually opened for adaptation and preparing the grafting seedlings for transplanting in the plastic house.

Transplants of grafted and non-grafted watermelon were transplanted in the open field on 10 and 4 April 2012 and 2013 respectively. The treatments were set in three replicates. Each plot contained 15 plants and consisted of one row 18 meter length and 2.5 meter width. The space between plants was $1.2 \mathrm{~m}$. The plants were irrigated using drip irrigation lines and fertilized with $1 \mathrm{~m} 3$ farm yard manure, $120 \mathrm{~kg} \mathrm{~N}, 60$ $\mathrm{kg} \mathrm{P} 2 \mathrm{O} 5$ and $150 \mathrm{~kg} \mathrm{~K} 2 \mathrm{O} / \mathrm{fed}$. Other cultural practices; such as plant protection against weeds, diseases and insects; were performed whenever they were thought to be necessary as recommended for commercial watermelon production under open field conditions.

\section{Measurements}

1. Survival rate. Live grafted plants were counted at the end of the season and survival rate was expressed as a percentage of the total number of survival plants by the total number of established plants two weeks after transplanting

2. Flowering time: It was expressed as the number of days required from transplanting until appearances (anthesis) of the first female flowers.

3. Vegetative growth characters: At the end of harvest data were recorded on percentage of plant cover $2 \mathrm{~m} 2$, number of branches and length of the main stem recorded on 10 plants in the middle of plot.

\section{Yield and fruit characters:}

Ripe fruits were harvested from 14 June to 5 July 2012 and from 9 June to 30 June 2013. All fruits were counted and individually weighed immediately after harvest. Thereafter, diameter and length of each fruit was measured and fruit shape index was calculated by dividing fruit length on fruit diameter. Five fruits from each plot were randomly chosen throughout the harvesting period to assess the fruit rind thickness and total soluble solids content of the fruit juice using a hand refractometer., according to the methods of A.O.A.C. (1975). Total weight and total number of fruits per plant were determined by dividing the total weight and total number of harvested fruits per plot, respectively by number of plants in each plot. On the other hand, total yield of each plot was calculated by summation the weights of all harvest fruits all over the harvesting season, and such data were converted to total yield per feddan (tons)

The Experimental Design and Statistical Analysis:

The experimental design was a Completely Randomized Design (CRD) with three replications. Data were subjected to an analysis of variance by COSTAT statistical program Revised Least Significant Difference test was used for the comparison among treatment's means (Gomez and Gomez, 1984).

\section{Results and Discussion}

\section{Survival rates:}

Data in Table 1 revealed that all rootstocks in 2012 season recorded a higher percentage of survival than ungrafted control. The percentage of survival ratios ranged from $82.0 \%$ to $100 \%$. Except for 'Kazako' rootstock, all rootstocks exceeded 93\% survival. No plants died until the end of the season in 'Emphasis' and 'Argentario', where they achieved $100 \%$ survival. In contrast, 36 per cent of nongrafted plants were died in the present study due to wilt at different stages of their life, mostly at vegetative and fruiting stages. Wilted plants were tested randomly in the laboratory and causal organism in non-grafted plants was found Fusarium spp. This pathogen was not found in the roots of all grafted plants. Salam et al. (2002), Yetisir et al. (2007), Taylor et al. (2008) and Mohammed et al. (2012) also observed all grafted watermelon plants were alive up to harvesting.

Table 1. Effect of rootstock types on pathogen infections of watermelon roots (summer season of 2012)

\begin{tabular}{ccllllll}
\hline Rootstock & R.solani & F.solani & M.phaseoli & F.Oxysporum & $\begin{array}{c}\text { Pythium } \\
\text { spp }\end{array}$ & $\begin{array}{c}\text { Trichoderma } \\
\text { spp }\end{array}$ & Nematodes \\
\hline Nongrafted & & & & $\sqrt{ } \sqrt{ }$ & $\sqrt{ }$ & $\sqrt{ }$ & $\sqrt{ }$ \\
(Aswan) & & & $\sqrt{ } \sqrt{ }$ & & $\sqrt{ }$ & & \\
6001 & & $\sqrt{ } \sqrt{ }$ & & $\sqrt{ }$ & $\sqrt{ }$ & \\
Squash 3 & & & $\sqrt{ } \sqrt{ }$ & & $\sqrt{ }$ & $\sqrt{ }$ & \\
Kazako & & $\sqrt{ }$ & $\sqrt{ } \sqrt{ }$ & & & $\sqrt{ }$ \\
Emphasis & & $\sqrt{ }$ & $\sqrt{ } \sqrt{ }$ & & & & \\
\hline
\end{tabular}

\begin{tabular}{lll}
\hline Argentario & $\sqrt{ } \sqrt{ }$ & $\sqrt{ } \sqrt{ }$ \\
\hline $\begin{array}{l}\text { = Pathogens found in one replicate; } \\
\text { replicates }\end{array}$ &
\end{tabular}

The method of disease control afforded by grafting is not well understood. It is presumed that the primary method is by avoidance when the rootstock is resistant to the pathogen (Boughalleb et al., 2008; King et al., 2008). Substances associated with Fusarium tolerance are synthesized in the root and 
translocated to the scion through the xylem system (Biles et al., 1989) and the activity of the substances released to disease resistance may vary during the development stages of the grafted plants (Heo, 1991).
On the other hand Pythium spp may be responsible for wilting in 6001, Squash 3 and Kazako in addition to Aswan (Table 1).

Table 2. Effect of rootstock on survival (\%) of watermelon plants in the two summer seasons of 2012 and 2013

\begin{tabular}{ccccccc}
\hline Rootstock & $\begin{array}{c}\text { Total plant } \\
\text { / plot }\end{array}$ & $\begin{array}{c}\text { Season 1 (2012) } \\
\text { No. of survival } \\
\text { plant }\end{array}$ & $\begin{array}{c}\text { Survival } \\
(\%)\end{array}$ & $\begin{array}{c}\text { Total plant } \\
\text { / plot }\end{array}$ & $\begin{array}{c}\text { Season 2 (2013) } \\
\text { No. of survival } \\
\text { plant }\end{array}$ & $\begin{array}{c}\text { Survival } \\
(\%)\end{array}$ \\
\hline $\begin{array}{c}\text { Nongrafted } \\
\text { (Aswan) }\end{array}$ & 15 & 9.7 & 64.4 & 15 & 15 & 100 \\
$\mathbf{6 0 0 1}$ & 15 & 14.0 & 93.3 & 15 & 15 & 100 \\
Squash 3 & 15 & 14.3 & 95.6 & 15 & 15 & 15 \\
Kazako & 15 & 12.3 & 82.2 & 15 & 15 & 100 \\
Emphasis & 15 & 15.0 & 100 & 15 & 15 & 100 \\
\hline Argentario & 15 & 15.0 & 100 & 15 & 15 & 100 \\
\hline
\end{tabular}

The survival rate of grafted plants depends on some factors, namely compatibility between scion and rootstock, quality and age of seedlings, quality of the joined section, post-grafting management and resistance of rootstock to soil borne diseases. Different grafting techniques are adapted for different scions and rootstocks depending on grafting objectives, farmer's experience, and post-grafting management conditions (Hang et al., 2005). The soil was turned (Up side down) in the second season, therefore no diseases infection was recorded and the survival percentages were $100 \%$ in all treatments, including nongrafted control. These results revealed that the causes of differences in survival percentages that recorded in the first season between the different rootstocks are attributed to the differences in the resistance to soil borne diseases. Similar results were reported in different previous investigations. In this regard, Boughalleb et al. (2007) revealed that watermelon seedlings grafted onto Strongtosa , TZ 148, Emphasis, Achille and Ercole were resistant to Tunisian isolates of Fusarium solani f. sp. cucurbitae and Fusarium oxysporum f. sp. niveum. Johnson and Miles (2011) found that Crisp'n Sweet watermelon grafted onto 'Emphasis' and 'Strongtosa' rootstock had significantly less Verticillium wilt severity than non- grafted and self- grafted watermelon. In addition, Al-Debei et al. (2012) reported that cucumber plants grafted on Strongtosa, Shintosa supreme and Tetsukabuto had $100 \%$ survival rate as compared to non-grafted plants where $32-43 \%$ were infected with Rhizoctonia solani and Pythium .

\section{Flowering time:}

Data presented in Tables 3 and 4 reveale nonsignificant effect for grafting on flowering time of female flowers (days from transplanting to first flowering female flower). Similarly, no significance difference was observed in days to 1 st male and female flower appearances by Salam et al. (2002) and Islam et al. (2013). Other reports recorded different results; Satoh (1996) revealed that grafting watermelon over bottle gourd [ Lagenaria siceraria (Mol.) Standl.] results in early formation of female flowers. Yetisir and Sari (2003), found that female flowers also opened 4-8 days earlier in grafted plants than in control plants except for the plants grafted onto rootstock LSC. However, the differences between flowering of watermelon plants, that were grafted onto Empasis rootstock in their study did not differ from nongrafted plants, which is in agreements with the present results. In contrast, in some cases like pumpkin (Cucurbita maxima Duchesne), bottle gourd, wax gourd [ Benincasa hispida (Thunb.) Cogn.] and watermelon-grafted watermelon, especially in plants with 'Shintoza'-type rootstocks (C. maxima Duchesne $\times$ C. moschata Duchesne), flowering was delayed (Yamasaki et al., 1994)

\section{Vegetative growth characters}

Data in Table 3 indicate that all rootstocks caused significant increment in plant length as compared with non grafted watermelon plants. Such results were true in both seasons. On the other hands, all grafted plants exhibited significantly more vigor (cover) than non-grafted (control) in the first season. In the second season, plants grafted on Argentario rootstock were only significantly superior in their vigor than non-grafted ones. Although all other plants, that were grafted on the other rootstocks, had also more vigor than the non-grafted plants, but without significant differences. Concerning the differences among different rootstocks on plant covering percentage, Argentario rootstock resulted in the highest percentage of plant cover $(98.33 \%$ and $95.00 \%$ in the first and second season, respectively), while Kazako rootstock had the lowest percentage of plant cover $(66.67 \%$ and $86.67 \%$ in the first and 
second season, respectively), with significant differences between the two rootstock only the first season. Vigorous plant growth in grafted watermelon was observed in several studies (e.g., Yetisir et al., 2007; Boughalleb et al., 2008; Mohammed et al., 2012). These increased vegetative growth may be due to the increasing in the area connection and the speedily differentiation from callus or cambium to vascular tissues (xylem and phloem) in the union area in the scion and rootstock of Argentario as compared with Kazako rootstock. In addition, Argentario rootstock might induce more amounts from gibberellins and auxins.

Table 3. Effect of rootstock types on number of days from transplanting until appearance of the first female flower and vegetative growth characters of watermelon in the summer seasons of 2012 and 2013.

\begin{tabular}{|c|c|c|c|c|c|c|c|c|}
\hline \multirow[t]{2}{*}{ Rootstock } & \multicolumn{2}{|c|}{$\begin{array}{c}\text { Days from } \\
\text { transplanting to } \\
\text { appearance of first } \\
\text { female flower }\end{array}$} & \multicolumn{2}{|c|}{ Plant covering $(\%)$} & \multicolumn{2}{|c|}{$\begin{array}{l}\text { No. Of side } \\
\text { shoots/plant }\end{array}$} & \multicolumn{2}{|c|}{ Plant length (m) } \\
\hline & 2012 & 2013 & 2012 & 2013 & 2012 & 2013 & 2012 & 2013 \\
\hline $\begin{array}{c}\text { Nongrafted } \\
\text { (Aswan) }\end{array}$ & $33.3 \mathrm{~A}$ & $33.8 \mathrm{~A}$ & $46.67 \mathrm{~A}$ & $80.00 \mathrm{~A}$ & $7.67 \mathrm{~A}$ & $8.000 \mathrm{~A}$ & $3.233 \mathrm{~A}$ & $4.167 \mathrm{~B}$ \\
\hline 6001 & $34.6 \mathrm{~A}$ & $34.6 \mathrm{~A}$ & $85.00 \mathrm{C}$ & $90.00 \mathrm{AB}$ & $10.00 \mathrm{~B}$ & $7.667 \mathrm{~A}$ & $5.057 \mathrm{C}$ & $5.317 \mathrm{~A}$ \\
\hline Squash 3 & $35.3 \mathrm{~A}$ & $34.0 \mathrm{~A}$ & $86.67 \mathrm{C}$ & $85.00 \mathrm{AB}$ & $10.33 \mathrm{~B}$ & $8.667 \mathrm{~A}$ & $5.743 \mathrm{C}$ & $5.367 \mathrm{~A}$ \\
\hline Kazako & $35.3 \mathrm{~A}$ & $34.3 \mathrm{~A}$ & $66.67 \mathrm{~B}$ & $86.67 \mathrm{AB}$ & $10.00 \mathrm{~B}$ & $9.333 \mathrm{~A}$ & $4.547 \mathrm{~B}$ & $5.833 \mathrm{~A}$ \\
\hline Emphasis & $35.3 \mathrm{~A}$ & $33.8 \mathrm{~A}$ & $93.33 \mathrm{C}$ & $88.33 \mathrm{AB}$ & $9.33 \mathrm{~B}$ & $9.833 \mathrm{~A}$ & $4.323 \mathrm{~B}$ & $5.333 \mathrm{~A}$ \\
\hline Argentario & $37.7 \mathrm{~A}$ & $34.3 \mathrm{~A}$ & $98.33 \mathrm{C}$ & $95.00 \mathrm{~B}$ & $12.00 \mathrm{C}$ & $9.333 \mathrm{~A}$ & $5.217 \mathrm{C}$ & $5.433 \mathrm{~A}$ \\
\hline
\end{tabular}

The difference between the results in the two seasons concerning percentage of cover is attributed to inverting the soil and bringing the lower soil layer into the soil surface in the second season. Such lower soil layer had no soil borne diseases; therefore, the growth of watermelon plants in such new soil layer was generally healthy. However, grafting caused more stimulation for plant growth that reached the significance concerning Argentario rootstock. These results indicated the importance of grafting in stimulating plant growth. These results are in agreement with those obtained by El-Eslamboly (2010), Bletsos (2005) and Alan et al. (2007) who found that, grafting watermelon positively affected on plant vigor and height. Also, Abd El-Wanis et al. (2013) found that grafting of watermelon (Aswan F1 hybrid) on bottle gourd rootstock (Lagenaria siceraria) local variety showed significant increment in most studied vegetative growth characteristics (plant height, stem diameter, leaf area, number of leaves, number of branches, plant fresh and dry weight and dry matter percentage), as compared with non-grafted watermelon (control). Promoted watermelon plant growth in the grafted plants can be explained by increased water and plant nutrient uptake (Pulgar et al., 2000), due to stronger and more extensive root growth of the rootstock (bottle gourd) (Zijlstra et al., 1994) The rootstocks vigorous root system is often capable of absorbing water and nutrients more efficiently than scion roots, and may serve as a supplier of additional endogenous plant hormones (Proebsting et al., 1992; Lee, 1994; Pulgar et al., 2000; Dong et al., 2008). No significant differences in number of branches per plant were noticed between grafted and non-grafted plants in the second season. However, the superiority of grafted plants in their covering percentage indicted that branches lengths in grafted plants were longer than that in non-grafted plants. The result of Islam et al. (2013) revealed that among growth parameters only length of the main vine was significantly higher in grafted plants than that of non-grafted plants. Salam et al. (2002) reported also, that both the length of vine and number of lateral branches produced in the grafted plants were higher than those of the nongrafts. The increase in the vegetative growth may be attributed to enhancing nutrient uptake by grafting (Ruiz et al., 1997; Colla et al., 2010b). SalehiMohammadi et al. (2009) reported that the influence of the rootstock on the mineral content in aerial plant parts may be attributed to the physical characteristics of the root system, such as lateral and vertical development, which result in enhanced uptake of water and minerals

\section{Yield and yield components}

Results of weight and number of fruit per plant and fruits weight and total yield are presented in Table 4. Total yield was generally significantly affected in both seasons by rootstock. However, such response was different in the first season than in the second one.

In the first season, all rootstocks produced significantly higher yield than control. In this respect all types of rootstocks produced 30-127 \% higher yields compared with the control. The highest yield was obtained from Argentario with 18.193 ton/fed, while the lowest yield was recorded in the graft combination of 6001 with 10.395 ton/fed. In contrast, the control plants produced the lowest total yield with 7.987 ton/fed. Plants grafted onto Lagenaria type rootstocks produced larger fruit than control plants and the plants grafted on Cucurbita type rootstocks. 
Table 4. Effect of rootstock types on plant productivity and total yield of watermelon in the summer seasons of 2012 and 2013.

\begin{tabular}{|c|c|c|c|c|c|c|c|c|}
\hline & \multicolumn{2}{|c|}{$\begin{array}{c}\text { Weight of fruits } \\
\text { (kg/ plant) }\end{array}$} & \multicolumn{2}{|c|}{$\begin{array}{c}\text { Number of fruits } \\
\text { per plant }\end{array}$} & \multicolumn{2}{|c|}{$\begin{array}{c}\text { Average fruit Weight } \\
\text { (kg) }\end{array}$} & \multicolumn{2}{|c|}{$\begin{array}{c}\text { Total yield } \\
\text { (ton/feddan) }\end{array}$} \\
\hline & 2012 & 2013 & 2012 & 2013 & 2012 & 2013 & 2012 & 2013 \\
\hline $\begin{array}{l}\text { Nongrafted } \\
\text { (Aswan) }\end{array}$ & $\begin{array}{c}8.529 \\
\mathrm{AB}\end{array}$ & $\begin{array}{l}11.555 \\
\mathrm{AB}\end{array}$ & $2.39 \mathrm{C}$ & $2.24 \mathrm{~A}$ & $3.569 \mathrm{~A}$ & $5.170 \mathrm{~A}$ & $7.987 \mathrm{~A}$ & $\begin{array}{c}16.178 \\
\mathrm{~B}\end{array}$ \\
\hline 6001 & $7.830 \mathrm{~A}$ & $\begin{array}{c}12.619 \\
\mathrm{BC}\end{array}$ & $1.54 \mathrm{~A}$ & $2.13 \mathrm{~A}$ & $5.084 \mathrm{BC}$ & $5.924 \mathrm{~B}$ & $10.395 \mathrm{~B}$ & $\begin{array}{c}17.667 \\
\mathrm{CD}\end{array}$ \\
\hline Squash 3 & 9.803 B & $\begin{array}{c}11.071 \\
\mathrm{AB}\end{array}$ & $2.09 \mathrm{BC}$ & $1.86 \mathrm{~A}$ & $4.690 \mathrm{~B}$ & $5.952 \mathrm{BC}$ & $13.928 \mathrm{C}$ & $\begin{array}{l}15.500 \\
\mathrm{~B}\end{array}$ \\
\hline Kazako & $\begin{array}{c}9.248 \\
\mathrm{AB}\end{array}$ & $\begin{array}{c}10.153 \\
\text { A }\end{array}$ & $2.02 \mathrm{AB}$ & $1.83 \mathrm{~A}$ & $5.054 \mathrm{~B}$ & $5.548 \mathrm{~A}$ & $11.137 \mathrm{~B}$ & $\begin{array}{c}14.213 \\
\mathrm{~A}\end{array}$ \\
\hline Emphasis & $\begin{array}{l}9.017 \\
\mathrm{AB}\end{array}$ & $\begin{array}{l}12.888 \\
\mathrm{BC}\end{array}$ & $1.89 \mathrm{AB}$ & $2.05 \mathrm{~A}$ & $4.771 \mathrm{~B}$ & $6.287 \mathrm{C}$ & $13.527 \mathrm{C}$ & $\begin{array}{c}18.043 \\
\mathrm{C}\end{array}$ \\
\hline Argentario & $12.129 \mathrm{C}$ & $13.164 \mathrm{C}$ & $2.19 \mathrm{BC}$ & $2.21 \mathrm{~A}$ & $5.538 \mathrm{C}$ & $5.956 \mathrm{BC}$ & $\begin{array}{c}18.193 \\
\mathrm{D}\end{array}$ & $\begin{array}{c}18.433 \\
\mathrm{D}\end{array}$ \\
\hline
\end{tabular}

The effect of rootstock types on average fruit weight took a similar trend to that recorded on total yield per feddan. However, the largest fruit was obtained from grafting on Argentario and 6001 with $5.538 \mathrm{~kg}$ and $5.084 \mathrm{~kg}$, respectively, while the fruit in control weighed $3.569 \mathrm{~kg}$. The smallest fruit was obtained from using of Squash 3 with $4.690 \mathrm{~kg}$. Total yield of fruits per plant was significantly affected by Argentario only, where grafting on this rootstock resulted on significant increase in plant yield as compared with nongrafted control, producing 12.129 $\mathrm{kg}$ and $8.529 \mathrm{~kg}$, respectively. Meanwhile, no significant differences were recorded between all other rootstocks and control regarding total fruit weight per plant. Number of fruits per plant was also significantly affected by rootstocks. Plants grafted on Argentario rootstocks and control plants had more number of fruits than plants grafted on 6001 rootstocks. The highest number of fruits per plant was produced by the control and followed by grafting on Argentario with 2.39 and 2.19 fruit per plant, respectively, while plants grafted on 6001 rootstock produced only 1.54 fruit per plant. All type rootstocks had higher vegetative growth parameters and plants grafted on Argentario were superior in this respect, while plants grafted on Kazako had the lowest percentage of covering and plants grafted on Emphasis had the lowest number of side shoots/plant and plant length. On the other hand, the percentage of survival ratios for grafted plants ranged from $82.0 \%$ (in 'Kazako') to $100 \%$. (in 'Emphases' and Argentario'), while it was $64.4 \%$ only in the nongrafted control plants. Thus, rootstocks types produced higher total yield per feddan and higher average fruit weight in the first season than control. Many authors have stated that rootstocks promoted yield in grafted plants (Nielsen and Kappel 1996; Ruiz and Romero 1999; Chouka and Jebari 1999). These effects can be explained by the interaction of some or all of the following phenomenons: increased water and plant nutrient absorption (Kato and Lou 1989; Ruiz et al. 1997; Colla et al. 2010b), augmented endogenous hormone production (Proebsting et al. 1992; Lee, 1994; Zijlstra et al., 1994; Pulgar et al., 2000; Dong et al., 2008), enhanced scion vigor (Leoni et al., 1990; Ito 1991), resistance to soil pathogens (Lee 1994). In our study, plant growth and survival percentage were significantly affected by rootstocks and these two characters were closely related to fruit yield. Additive effects of the processes mentioned above can also help to explain yield increases.

In the second season, there was significant increase in weight of fruits per plant due to grafting on Argentario. On the other hand, except Kazako, which not only had no significant effect on average fruit weight, but also caused a significant decrease in total yield per feddan as compared with nongrafted control, all other rootstocks resulted in significant increase in average fruit weight and total yield per feddan as compared with Kazako and nongrafted control (Table 6). Grafted plants produced 9-13\% higher yield than the control, while Kazako rootstock had $12 \%$ less yield than the control. This could be attributed to incomplete compatibility of Kazako rootstock. According to Yetisir et al. (2003), plants grafted onto Lagenaria-type rootstocks produced larger fruit than non-grafted plants. In another study, Miguel et al. (2004) found that the 'Shintosa' rootstock increased fruit size compared to the nongrafted plants. Richardez-Salinas et al. (2010) found that the use of melon grafted on 'RS-841' and 'Shintosa Camelforce' rootstocks significantly increased the average fruit weight . In Egypt, Kapiel et al. (2005) and Abd El-Wanis et al. (2013) observed that the fruit size of watermelons grafted to rootstocks having vigorous root systems is often significantly increased compared to fruits from intact 
plants. Because no plants were died in the second season, the increase in total yield plant growth characters, especially covering percentage and plant length which may be attributed to increased water and plant nutrient absorption (Kato and Lou 1989; Ruiz et al., 1997; Colla et al., 2010b), augmented endogenous hormone production (Zijlstra et al. 1994).

\section{Fruit characters:}

Length and diameter of fruit and rend thickness of fruit in the first year and TSS\% in the second season (Table 5) were influenced by grafting. In the first season, grafting on 6001 and squash 3 significantly increased lengths of fruit, while grafting on Emphasis and Argentario significantly increased diameter of fruit as compared with the control. On the other hand, fruit shape in both seasons and length and diameter of fruits in the second season were not significantly affected by rootstocks. Similarly, Traka-
Mavrona et al. (2000) stated that fruit shape of melon cultivars was also not significantly affected by grafting onto any rootstock. As found by Alan et al. (2007) fruit shape indices of watermelon was not significantly affected by grafting. The present results show that fruits from grafted watermelon plants, in the first season, had a thicker rind than non-grafted plants, however, the differences between Squash 3 and control were not significant in this concern. The increase in rind thickness was higher by $57.6 \%$ in 'Kazako' $53.6 \%$ in 'Emphasis', $34.6 \%$ in '6001' and $36 \%$ in 'Argentario' as compared to control. Grafting in the second season on 'Kazako', 'Emphasis' and 'Squash 3' caused also increase in fruit rind as compared to control, but this increase was not significant. Fruits from grafted watermelon plants had a thicker rind than non-grafted plants (Alexopoulos et al., 2007; El-Eslamboly, 2010; Turhan et al., 2012).

Table 5. Effect of rootstock types on some physical and chemical fruit characters of watermelon in the summer seasons of 2012 and 2013.

\begin{tabular}{ccccccccccc}
\hline \multirow{2}{*}{ Rootstock } & \multicolumn{2}{c}{$\begin{array}{l}\text { length of fruit } \\
\text { (cm) }\end{array}$} & \multicolumn{2}{c}{$\begin{array}{c}\text { Diameter of } \\
\text { fruit(cm) }\end{array}$} & Fruit shape & \multicolumn{2}{c}{$\begin{array}{c}\text { Rend of } \\
\text { fruit(cm) }\end{array}$} & \multicolumn{2}{c}{ TSS\% } \\
\cline { 2 - 11 } Nongrafted & 2012 & 2013 & 2012 & 2013 & 2012 & 2013 & 2012 & 2013 & 2012 & 2013 \\
(Aswan) & 20.57 & 27.03 & 20.05 & 23.50 & 1.03 & 1.15 & 1.51 & 1.75 A & 9.75 & 12.50 \\
\multirow{6}{6001}{} & $\mathrm{A}$ & $\mathrm{A}$ & $\mathrm{A}$ & $\mathrm{A}$ & $\mathrm{A}$ & $\mathrm{A}$ & $\mathrm{A}$ & & $\mathrm{A}$ & $\mathrm{B}$ \\
& 23.29 & 27.67 & 21.65 & 24.17 & 1.08 & 1.14 & 1.94 & $1.75 \mathrm{~A}$ & 9.57 & 11.50 \\
Squash 3 & $\mathrm{B}$ & $\mathrm{A}$ & $\mathrm{AB}$ & $\mathrm{A}$ & $\mathrm{A}$ & $\mathrm{A}$ & $\mathrm{BC}$ & & $\mathrm{A}$ & $\mathrm{AB}$ \\
& 24.67 & 27.67 & 21.95 & 23.83 & 1.12 & 1.16 & 1.71 & $1.92 \mathrm{~A}$ & 9.15 & 11.17 \\
Kazako & $\mathrm{B}$ & $\mathrm{A}$ & $\mathrm{AB}$ & $\mathrm{A}$ & $\mathrm{A}$ & $\mathrm{A}$ & $\mathrm{AB}$ & & $\mathrm{A}$ & $\mathrm{A}$ \\
& $\mathrm{AB}$ & $\mathrm{A}$ & $\mathrm{AB}$ & $\mathrm{A}$ & $\mathrm{A}$ & $\mathrm{A}$ & & & $\mathrm{A}$ & $\mathrm{AB}$ \\
Emphasis & 23.53 & 27.67 & 22.20 & 23.83 & 1.04 & 1.16 & $2.04 \mathrm{C}$ & $1.92 \mathrm{~A}$ & 8.68 & 11.17 \\
& $\mathrm{AB}$ & $\mathrm{A}$ & $\mathrm{B}$ & $\mathrm{A}$ & $\mathrm{A}$ & $\mathrm{A}$ & & & $\mathrm{A}$ & $\mathrm{A}$ \\
\hline \multirow{2}{*}{ Argentario } & 22.77 & 27.67 & 22.27 & 23.60 & 1.02 & 1.17 & 1.87 & $1.75 \mathrm{~A}$ & 9.37 & 11.17 \\
& $\mathrm{AB}$ & $\mathrm{A}$ & $\mathrm{B}$ & $\mathrm{A}$ & $\mathrm{A}$ & $\mathrm{A}$ & $\mathrm{BC}$ & & $\mathrm{A}$ & $\mathrm{B}$ \\
\hline
\end{tabular}

TSS (total soluble solids) ranged from 8.683 to 9.750 $\%$ in the first season 11.17 to $12.50 \%$ in the second season. Our results showed that TSS contents were significantly influenced by grafting. Fruit TSS contents of non-grafted plants were significantly higher, in the second season, than that of the plants grafted showing negative effects of rootstocks on fruit TSS contents. Several authors also reported that grafting onto various rootstocks decreased soluble solids (Alexopoulos et al., 2007; Lopez-Galarza et al., 2004). Some researchers reported a significant reduction of fruit TSS in fruit of the grafted watermelon (Yamasaki et al., 1994, Turhan et al., 2012), melon (Bie et al., 2010) and tomato (Turhan et al., 2011). The total sugar content of watermelons grafted onto bottle gourd rootstock was reported to be lower than in self-rooted watermelons (Yao et al., 2003; Lopez-Galarza, et al., 2004; Liu et al., 2006; Alexopoulos, et al., 2007. On the contrary, Salam et al. (2002) showed a marked increase in watermelon TSS content when grafted onto bottle gourd. On the other hand, other scientists found no difference in soluble solids between grafted and non-grafted (Bruton et al., 2009; Miguel et al., 2004). In addition, it appears that sugar accumulation in mature fruit varies with rootstocks (Gao and Liao 2006; Xu et al., 2006b).

The study showed the importance of using grafting in heavily infected with soil borne diseases and importance of choosing the rootstocks that positively influence plant growth as well as yield and quality of scion fruit for the commercial use of grafting in watermelon fields.

\section{References}

Abd El-Wanis, M, El-Eslamboly A.A.S.A. and Salama, M. A. (2013). Impact of different grafting methods on yield and quality of watermelon. Res. J. Agric. \& Bio. Sci., 9(6): 330-340. 
Alan, O., N. Ozdemir and Y. Gunen, 2007. Effect of grafting on watermelon plant growth, yield and quality. J. Agron., 6(2): 362-365.

Al-Debei, H.S., Makhadmeh, I, Abu-Al Ruz, I., AlAbdallat, A.M., Ayad, J.Y. and Al Amin, N. (2012). Influence of different rootstocks on growth and yield of cucumber (Cucumis sativus L.) under the impact of soil-borne pathogens in Jordan. Journal of Food, Agriculture \& Environment Vol.10 (2): 343-349.

Alexopoulos, A.A., A. Kondylis, and H. Passam. 2007. Fruit yield and quality of watermelon in relation to grafting. J. Food Agr. Environ. 5:178-189.

A.O.A.C. (1975). Official Methods of Analysis of the Association of Official Agriculture Chemists. 12th Ed. Published By the A.O.A.C., Washington, D.C., U.S.A, 870pp.

Arao T, Takeda H and Nishihara E (2008) Reduction of cadmium translocation from roots to shoots in eggplant (Solanum melongena ) by grafting onto Solanum torvum rootstock. Soil. Sci. Plant Nutr., 54:555-559

Bersi M (2002) Tomato grafting as an alternative to methyl bromide in Marocco. Institut Agronomieque et Veterinaire Hasan II, Marocco.

Biles, C.L., Martyn, R.D. and Wilson, H.D. (1989). Isoenzymes and general proteins from various watermelon cultivar and tissue types. HortScience, 24:810-812.

Bletsos, F.A. (2005). Use of grafting and calcium cyanamide as alternatives to methyl bromide soil fumigation and their effects on growth, yield, quality and fusarium wilt control in melon. Journal of Phytopathology, 153: 155161.

Boughalleb, N., Mhamdi, M. , El Assadi, B. , El Bourgi, Z., Tarchoun, N. and Romdhani, M.S. (2008). Resistance evaluation of grafted watermelon (Citrullus lanatus L.) against Fusarium wilt and Fusarium crown and root rot. Asian J. Plant Patho. 2:24-29.

Boughalleb N, Tarchoun N, El-Mbarki A, ElMahjoub M (2007). Resistance evaluation of nine cucurbit rootstocks and grafted watermelon (Citrullus lanatus L.) varieties against fusariumwilt and fusarium crown and root rot. J Plant Sci 2: 102-107.

Bruton, B.D., W.W. Fish, W. Roberts, and T.W. Popham. 2009. The influence of rootstock selection on fruit quality attributes of watermelon. Open Food Sci. J. 3:5-34.

Chouka, A. S. and Hajer, J. (1999). Effect of grafting on watermelon vegetative and root development, production and fruit quality. Acta Hort. 492: 85-93.

Cohen, S. and Naor, A. (2002). The effect of three rootstocks on water use, canopy conductance and hydraulic parameters of apple trees and predicting canopy from hydraulic conductance. Plant Cell Environ 25:17-28

Colla G, Rouphael Y, Cardarelli M, Massa D, Salerno A and Rea E (2006) Yield, fruit quality and mineral composition of grafted melon plants grown under saline conditions. J Hort Sci Biotechnol., 81:146-152.

Colla, G., Rouphael, Y., Leonardi, C. and Bie, Z. ( 2010a). Role of grafting in vegetable crops grown under saline conditions. Sci. Hortic. 127 (2), 147-155.

Colla G, Suãrez CMC, Cardarelli M and Rouphael Y (2010b). Improving nitrogen use efficiency in melon by grafting. HortScience 45:559-565.

Davis, A. R. and Perkins-Veazie, P. (2005). Rootstock effects on plant vigor and watermelon fruit quality. Cucurbit Genet. Coop. Rpt., 28-29: 39-42.

Davis, A.R., Perkins-Veazie, P., Sakata, Y., LopezGalarza, S., Maroto, J.V., Lee, S.G., Huh, Y.C., Sun, Z., Miguel, A., King, S.R., Cohen, R., Lee, J.M. (2008). Cucurbit grafting. Crit. Rev. Plant Sci., 27: 50-74.

Dong, H.H, Niu, Y.H., Li, W.J. and Zhang, D.M. (2008) Effects of cotton rootstock on endogenous cytokinins and abscisic acid in xylem sap and leaves in relation to leaf senescence. J. Exp. Bot., 59:1295-1304

Edelstein ,M., Ben-Hur, M., Cohen, R., Burger, Y. and Ravina, I. (2005) Boron and salinity effects on grafted and nongrafted melon plants. Plant Soil, 269:273-284

El-Eslamboly, A.A.S. (2010). Studies on propagation of watermelon plants. . Ph.D. Thesis Agric. Sci. (Vegetable Crops), Fac. Agric., Cairo Univ., Cairo, Egypt, 150 p.

Fernández-García N, Martínez V, Cerda A and Carvajal M. (2004) Fruit quality of grafted tomato plants grown under saline conditions. J Hort Sci Biotechnol., 79:995-1001.

Gao, J. H. and Liao, H. J. 2006. Effect of grafting on watermelon quality, China

Cucurbits and Veg., 5: 12-14.

Gomez, K.A. and Gomez, A.A. (1984). Statistical Procedures for Agricultural Research. International Rice Research Institute, 2nd Ed. Joho Wiley and Sons. Inc. New- York, 680 p.

Hang, S.D., Zhao, Y.P., Wang, G.Y. and Song, G.Y. (2005). Vegetable Grafting, China Agriculture Press, Beijng, China.

Heo, Y.C. (1991). Effects of rootstocks on exudation and mineral elements contents in different parts of oriental melon and cucumber. MS Thesis, Kyung Hee Univ., Seoul, Korea.

Huh Y.C., Woo, Y.H., Lee, J.M, Om, Y.H (2003). Growth and fruit characteristics of watermelon grafted onto Citrullus rootstocks selected for disease resistance. J. Kor. Soc. Hortic. Sci., 44: 649-54. 
Ioannou N (2001) Integrating soil solarization with grafting on resistant rootstocks for management of soil-borne pathogens of eggplant. J. Hort. Sci. Biotechnol., 76:396-401.

Islam, M.S., Bashar, H.M.K., Howlader, M.I.A., Sarker, J.U., and Al-Mamun, M.H. (2013). Effect of grafting on watermelon growth and yield. Khon Kaen Agr. J. 41 Suppl. 1, 284-298.

Ito, T. (1991) Present state of transplant production practices in Japanese Horticultural Industry. in: Kurata, K. and Kozai, T. [Eds.] Transplant Production System. Kluwer Academic Publ., Yokohoma, Japan. pp. 65-82.

Johnson, S. and C. A. Miles. 2011. Effect of healing chamber design on the survival of grafted

eggplant, watermelon, and tomato. HortTechnology, 21(6):752- 758.

Kacjan-Marsic N and Osvald J (2004). The influence of grafting on yield of two tomato cultivars Lycopersicon esculentum Mill grown in a plastic house. Acta Agric Slovenica 83(2):243249

Kapiel, T., Rhodes, B., Dane, F. and. Zhang, X. (2005). Advances in watermelon breeding. Journal of New Seeds, 6(4): 289 -319

Kato, T. and H. Lou, 1989. Effects of rootstock on the yield, mineral nutrition and hormone (cytokinins, gibberellins and auxins) level in xylem sap in eggplant. Journal of the Japanese Society For Horticultural Science, 58(2): 345352.

King, S.R., Davis, A.R., Liu, W. and. Levi, A. (2008). Grafting for disease resistance. HortScience, 43:1673-1676

Lee JM (1994) Cultivation of grafted vegetables I: current status, grafting methods and benefits. HortScience, 29:235-239 .

Lee, J.M., Kubota, C., Tsao, S.J., Hoyos Echevarria, P., Morra, L. and Oda, M., (2010). Current status of Vegetable grafting: diffusion grafting techniques, automation. Sci. Hortic., 127, 93105.

Lee, J. M. and Oda, M. (2003). Grafting of herbaceous vegetable and ornamental crops. Hortic. Rev., 28: 61-124.

Lee, T. J., Sarwinski, S., Ishine, T., Lai, C.C. and Chen, F.Y. . 1996. Inhibition of cerebral neurogenic vasodilation by L-glutamine and nitric oxide synthase inhibitors and its reversal by L-citrulline. J. Pharmacol. Exp. Ther. 276: 353-358.

Leoni, S., R. Grudina, M. Cadinu, B. Madeddu, and M.G. Carletti. 1990. The influence of four rootstocks on some melon hybrids and a cultivar in greenhouse. Acta Hort. 287:127134.

Liu, H. Y., Zhu, Z. J., Diao, M., and Guo, Z. P. (2006). Characterisitic of the sugar metabolism in leaves and fruits of grafted watermelon during fruit development. Plant Physiol. Commun., 42: 835-840

Liu, H. Y., Zhu, Z. J., Lu, G. H., and Qian, Q. Q. (2003). Study on relationship between physiological changes and chilling tolerance in grafted watermelon seedlings under low temperature stress, Scientia Agriculturae Sinic, 36: 1325-1329.

.L’opez-Galarza, S., San Bautista, A., P'erez, D. M., Miguel, A., Baixauli, C., Pascual, B., Maroto, J. V. and Guardiola, J. L. (2004). Effects of grafting and cytokinin-induced fruit setting on colour and sugar-content traits in glasshousegrown triploid watermelon. J. Hort. Sci. \& Biotech., 79: 971-976.

Miguel, A., Maroto, J. V., San Bautista, A., Baixauli, C., Cebolla, V., Pascual, B., L'opez-Galarza, S., and Guardiola, J. L. (2004). The grafting of triploid watermelon is an advantageous alternative to soil fumigation. Scientia Hort., 103: 9-17.

Mohammed, F.H., Abd El-Hamed, K.E., Elwan, M.W.M., Hussein, M.N.E. (2012). Impact of grafting on watermelon on growth, fruit and quality. Veg. Crops Res. Bulletin 76:99-118.

Mounir, M. M. (1965). Physiological and anatomical response of fruits and plant of watermelon grafted on different cucurbita species. PhD. Thesis, Fac. Agric, Ain Shams Univ. Cairo. Egypt, pp. 172.

Neilsen, G. and F. Kappel. 1996. 'Bing' sweet cherry leaf nutrition is affected by rootstock. HortScience 31:1169-1172

Oda M. (1999). Grafting of vegetables to improve greenhouse production. Ext. Bull. Food Fert. Tech. Center, 480: 11.

Otani T and Seike N (2006) Comparative effects of rootstock and scion on dieldrin and endrin uptake by grafted cucumber ( Cucumis sativus). J. Pestic. Sci., 31:316-321.

Otani T and Seike N (2007) Rootstock control of fruit dieldrin concentration in grafted cucumber ( Cucumis sativus ). J. Pestic. Sci., 32:235-242

Proietti, S., Rouphael, Y., Colla, G., Cardarelli, M., De Agazio, M., Zacchini, M., Moscatello, S., Battistelli, A. (2008). Fruit quality of miniwatermelon as affected by grafting and irrigation regimes. J. Sci. Food. Agric., 88: 1107-1114.

Proebsting, W.M.P., Hedden, M.J., Lewis, S.J. and Croker-Proebsting, L.N. (1992). Gibberellin concentration and transport in genetic lines of pea. Plant Physiol., 100:1354-1360

Pulgar, G., Villora, G., Moreno, D.A., Romero, L. (2000). Improving the mineral nutrition in grafted watermelon plants: nitrogen metabolism. Biol. Plant., 43: 607-9.

Rouphael, Y., Cardarelli, M., Colla, G. and Rea, E. (2008a) Yield, mineral composition, water relations, and water use efficiency of grafted 
mini-watermelon plants under deficit irrigation. Hort Sci 43(3):730-736.

Rouphael, Y., Cardarelli, M., Rea, E., Colla, G. (2008b). Grafting of cucumber as a means to minimize copper toxicity. Environ Exp Bot., 63:49-58.

Ruiz, J.M., Belakbir, A., López-Cantarero, I. and Romero, L. (1997) Leaf-macronutrient content and yield in grafted melon plants. A model to evaluate the influence of rootstock genotype. Sci Hort., 71:227-234.

Salam, M. A., Masum, A. S. M. H., Chowdhury, S. S., Dhar, M., Saddeque, A., and Islam, M. R. (2002). Growth and yield of watermelon as influenced by grafting. OnLine J. Biol. Sci., 2: 298-299.

Satoh S (1996) Inhibition of flowering of cucumber grafted on rooted squash rootstocks. Physiol Plant 97:440-444

Salehi-Mohammadi R., Khasi A., Lee S.G., Huh Y.C., Lee J.M., Delshad M. (2009). Assessing survival and growth performance of Iranian mel-on to grafting onto Cucurbita root-stocks. Korean J. Hortic. Sci. Technol. 27(1): 1-6.

Savvas D, Papastavrou D, Ntatsi G, Ropokis A, Olympios C, Hartmann $\mathrm{H}$ and Schwarz D (2009) Interactive effects of grafting and Mnsupply level on growth, yield and nutrient uptake by tomato. Hort Sci., 44:1978-1982.

Scheffer RP (1957) Grafting experiments with Fusarium wilt resistant and susceptible tomato plants. Phytopathology, 47:30

Shinbori, F., Kota, N., and Yoshino, A. (1981). Studies on the maturation physiology and the quality of watermelon II Influence of rootstocks on the growth properties and the quality in grafting culture. Bull. Chiba Agric. Exp. Sta., 22: 21-27. (in Japanese with English summary)

Taylor M., B. Bruton, W. Fish and W. Roberts. 2008. Cost benefit analyses of using grafted watermelon transplants for Fusarium wilt disease control. Acta Hort., 782:343-350.

Traka-Mavrona, E., M. Koutsika-Sotiriou, and T. Pritsa. 2000. Response of squash (Cucurbita spp.) as rootstock for melon (Cucumis melo L.). Scientia Hort. 83:353-362.

Turhan, A ., Ozmen, N. Kuscu, H., Sitki Serbeci, M.and Vedat Seniz, V. 2012. Influence of rootstocks on yield and fruit characteristics and quality of watermelon. Hort. Environ.

Biotechnol. 53(4):336-341.

Xu, C. Q., Li, T. L. and Qi, H. Y. (2006a). Effects of grafting on development, carbohydrate content, and sucrose metabolizing enzymes activities of muskmelon fruit. Acta Hort. Sinica, 33: $773-$ 778.

Xu, C. Q., Li, T. L., Qi, H. Y. and Qi, M. F. (2006b). Effects of grafting on development and sugar content of muskmelon fruit. J. Shenyang Agr. Univ., 37: 378-381.

Xu, S. L., Chen, Q. Y., Li, S. H., Zhang, L. L., Gao, J. S., and Wang, H. L. (2005c). Roles of sugarmetabolizing enzymes and GA3, ABA in sugars accumulation in grafted muskmelon fruit. J. Fruit Sci., 22: 514-518.

Yamamuro, K. and Marukawa, S. (1974). Studies on the selection of Cucurbita spp. as watermelon rootstocks. 3. Compatibility and yield in relation to differences in cultivation. Bull. Ibaraki-ken Hortic. Exp. Station, 5:123-149.

Yamasaki A, Yamashita M and Furuya S (1994) Mineral concentrations and cytokinin activity in the xylem exudates of grafted watermelons as affected by rootstocks and crop load. J Jpn Soc Hort Sci., 62:817-826

Yao, F. J., Huang, D. F., Xu, J. H., Zhang, H. M., and Liu, Y. Q. (2003). Effects of rootstocks on growth and fruit quality of grafted watermelon, J. Shanghai Jiaotong Univ. (Agricultural Science) 21: 289-294.

Yetişir, H., Kurt, S., Sari, N. and Tok, F.M.. (2007). Rootstock potential of Turkish Lagenaria siceraria germplasm for watermelon: Plant growth, graft compatibility, and resistance to Fusarium. Turk J. Agric. For., 31:381-388

Yetisir, H. and Sari, N. (2003). Effect of different rootstock on plant growth, yield and quality of watermelon. Australian J. Expt. Agri., 43: 1269-1274.

Yetisir H., Sari, N., and Yucel, S. (2003). Rootstock resistance to fusarium wilt and effect on watermelon fruit yield and quality. Phytoparasitica, 31: 163-169.

Zijlstra, S., Groot, S.P.C. and Jansen, J. (1994). Genetic variation of rootstocks for growth and production in cucumber; possibilities for improving the root system by plant breeding. Sci. Hort., 56:185-186. 


\section{تأثير اصول الطعوم المختلفة على نمو النبات، والمحصول وجودة البطيخ}

$$
\begin{aligned}
& \text { سيد فتحى السبد 1،حسن على حسن 1، محمد عبد الفتاح جعارة } 2 \\
& 1 \text { قسم الخضر ، كلية الزراعـة ، جامعـة القاهــة، الجـيزة ،مصـر . } \\
& \text { 2 مزرعـة محطـة التجـارب لشركة ساكات اللبذور،الاسماعيلية،مصر . }
\end{aligned}
$$

اجريت هذه الدراسة في المزرعة التجريبية لنركة البذور ساكاتا، التى تقع في محافظة الإسماعيلية ، مصر خلال الموسم الصيفى لعامى 2012 وعام 2013. نم تطعيم البطيخ(هجين أسوان)على 5 اصول مختلفة ، وهي ، Squash 3, Kazako, Emphasis and Argentario،6001. تم استخدام صنف البطيخ أسوانبدون تطعيم للمقارنة. زرعت النباتات في التربةالرملية تحنظروف الحقل المفتوح. وأظهرت النتائج أنه في حين كان

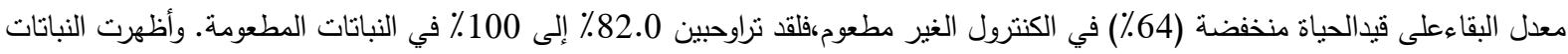

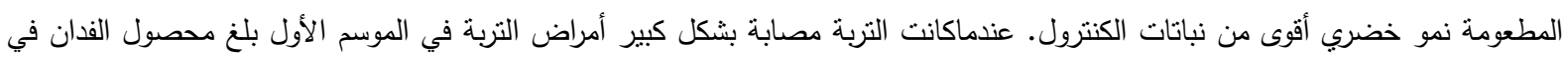

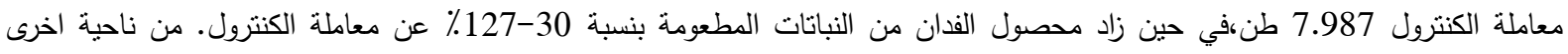
عندماكانت التربة خالية من أمراض التربة في الموسم الثاني بلغ محصول الفدان في معاملة الكنترول

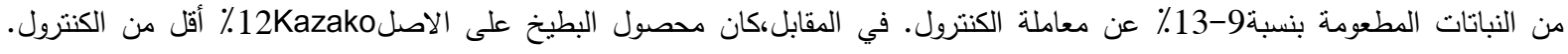

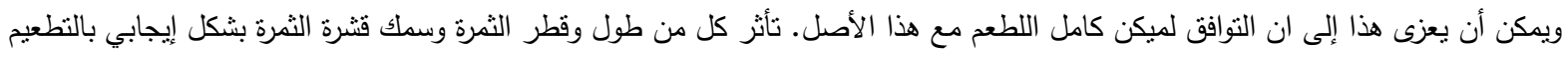
في السنة الأولى،بينما انخفضت النسبة المئوية للمواد الصلبة الذائبة (TSS\%) انخفاضا ملحوظا بالتطعيم في الموسم الثاني. وأظهرت الدراسةأهميةاستخدام التطعيم في التربة المصابة بثدة أمراض التربة وأهمة إختيار الطعم الذى يكون له نأثير ايجابى كبير على نمو النبات

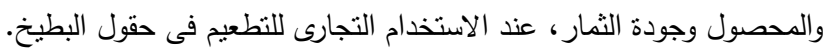
الكلمات الرئيسية: النطعيم ، معدل البقاءعلى قيد الحياة ، نمو النبات ، المحصول ، البطيخ. 